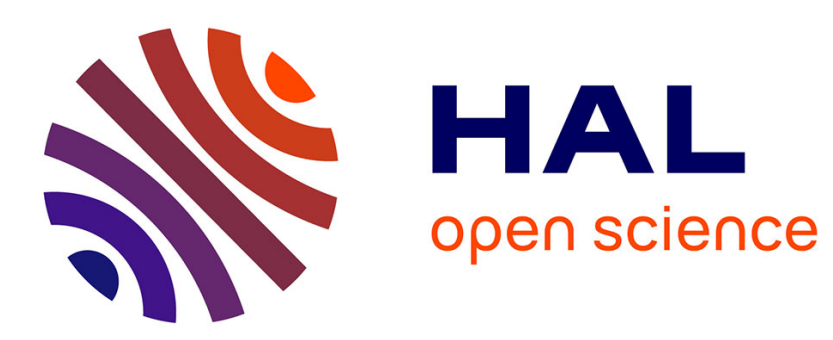

\title{
New Development in Rare Earth Metal Complexes Containing Anionic Bis(imino)pyrrolyl and Bis(phosphanyl)amide Ligands
}

Peter Roesky, Jelena Jenter, Tianshu Li

\section{- To cite this version:}

Peter Roesky, Jelena Jenter, Tianshu Li. New Development in Rare Earth Metal Complexes Containing Anionic Bis(imino)pyrrolyl and Bis(phosphanyl)amide Ligands. Journal of Inorganic and General Chemistry / Zeitschrift für anorganische und allgemeine Chemie, 2010, 636 (12), pp.2148. 10.1002/zaac.201000169 . hal-00568239

\section{HAL Id: hal-00568239 \\ https://hal.science/hal-00568239}

Submitted on 23 Feb 2011

HAL is a multi-disciplinary open access archive for the deposit and dissemination of scientific research documents, whether they are published or not. The documents may come from teaching and research institutions in France or abroad, or from public or private research centers.
L'archive ouverte pluridisciplinaire HAL, est destinée au dépôt et à la diffusion de documents scientifiques de niveau recherche, publiés ou non, émanant des établissements d'enseignement et de recherche français ou étrangers, des laboratoires publics ou privés. 


\section{Zeitschrift für Anorganische und}

Allgemeine Chemie

\section{New Development in Rare Earth Metal Complexes Containing Anionic Bis(imino)pyrrolyl and Bis(phosphanyl)amide Ligands}

\begin{tabular}{|c|c|}
\hline Journal: & Zeitschrift für Anorganische und Allgemeine Chemie \\
\hline Manuscript ID: & zaac.201000169.R1 \\
\hline Wiley - Manuscript type: & Research Report \\
\hline $\begin{array}{r}\text { Date Submitted by the } \\
\text { Author: }\end{array}$ & 18-May-2010 \\
\hline Complete List of Authors: & $\begin{array}{l}\text { Roesky, Peter; Karlsruher Institut fur Technologie (KIT), Institut fur } \\
\text { Anorganische Chemie } \\
\text { Jenter, Jelena; Karlsruher Institut fur Technologie (KIT), Institut fur } \\
\text { Anorganische Chemie } \\
\text { Li, Tianshu; Karlsruher Institut fur Technologie (KIT), Institut fur } \\
\text { Anorganische Chemie }\end{array}$ \\
\hline Keywords: & $\begin{array}{l}\text { Rare Earth Elements, } \mathrm{N} \text {-ligand, Coordination Compounds, Catalysis, } \\
\text { Chelates }\end{array}$ \\
\hline \multicolumn{2}{|c|}{$\begin{array}{l}\text { Note: The following files were submitted by the author for peer review, but cannot be converted } \\
\text { to PDF. You must view these files (e.g. movies) online. }\end{array}$} \\
\hline $\begin{array}{l}\text { zaac scheme } 1 . c d x \\
\text { zaac scheme } 10 . c d x \\
\text { zaac scheme } 11 . c d x \\
\text { zaac scheme } 12 . c d x \\
\text { zaac scheme } 13 . c d x \\
\text { zaac scheme } 14 . c d x \\
\text { zaac scheme } 15 . c d x \\
\text { zaac scheme 16.cdx } \\
\text { zaac scheme 17.cdx } \\
\text { zaac scheme 18.cdx } \\
\text { zaac scheme 2.cdx } \\
\text { zaac scheme 3.cdx } \\
\text { zaac scheme 4.cdx } \\
\text { zaac scheme 5.cdx } \\
\text { zaac scheme } 6 . c d x \\
\text { zaac scheme } 7 . c d x \\
\text { zaac scheme } 8 . c d x \\
\text { zaac scheme } 9 . c d x\end{array}$ & \\
\hline
\end{tabular}


zaac scheme entry.cdx

\section{5) scholaroNE \\ Manuscript Central}




\title{
RESEARCH REPORT
}

\section{New Development in Rare Earth Metal Complexes Containing Anionic Bis(imino)pyrrolyl and Bis(phosphanyl)amide Ligands}

\author{
Tianshu Li, ${ }^{[\mathrm{a}]}$ Jelena Jenter $^{[\mathrm{a}]}$ and Peter W. Roesky ${ }^{[\mathrm{a}]^{*}}$ \\ Keywords: Rare Earth Elements; N-ligand; Coordination Compounds; Catalysis; \\ Chelates
}

\begin{abstract}
Rare earth element complexes having the very bulky 2,5-bis $\{N-(2,6-$ diisopropylphenyl)iminomethyl pyrrolyl, and the sterically less demanding bis(phosphanyl)amide ligand, $\left(\mathrm{PPh}_{2}\right)_{2} \mathrm{~N}^{-}$, in the coordination sphere are reviewed in this research report. The coordination chemistry, the reactivity, and the catalytic application of the corresponding complexes are discussed.
\end{abstract}

* Prof. Dr. Peter W. Roesky

Fax: +49-721-608-4854

E-Mail: roesky@kit.edu

[a] Institut für Anorganische Chemie, Karlsruher Institut für Technologie (KIT), Geb. 30.45, Engesserstr. 15, D-76131 Karlsruhe, Germany 
Recently there has been tremendous research progress in the non-cyclopentadienyl chemistry $[1,2]$. In this research report, we emphasize on two different anionic amido ligands, an NNN tridentate bis(imino)pyrrolyl ligand and a PN bidentate bis(phosphanyl)amide ligand, and present our results in the synthesis and catalytic applications of the rare earth metal complexes containing these two ligands.

\section{Bis(imino)pyrrolyl Ligands}

\subsection{Introduction}

2,5-Bis $(N$-aryliminomethyl)pyrrolyl ligands are monoanionic ligands, which can be easily accessed by deprotonation of the corresponding bis(imino)pyrroles [3]. Bis(imino)pyrroles are prepared by condensation of 2,5-diformylpyrrole with the analogous anilines [4]. 2,5-Bis( $N$-aryliminomethyl)pyrrolyl ligands contain a pyrrolyl unit and two imino groups, which create three possible coordination sites. As shown in Scheme 1, bis(imino)pyrrolyl derivatives can act as bi- or tridentate chelating ligands to form either A or $\mathbf{B}$ coordination mode with a metal center [5].

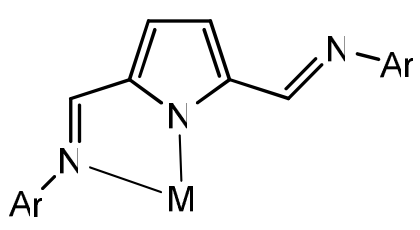

A

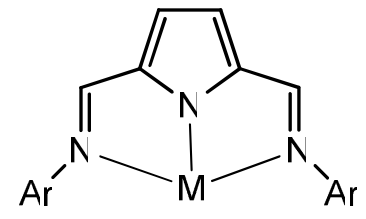

B

\section{Scheme 1}

The coordination mode of the resulting complexes depends on the nature of the arylsubstituents of the ligand, the number of ligands coordinated, the ionic radius of the metal center and the bulkiness of additional ligands coordinated to the metal atom. 2,5-Bis $(N-$ 
aryliminomethyl)pyrrolyl ligands have been introduced into main group and transition metals, such as aluminum [6], group 4 metals [7], chromium [8], iron [9], cobalt [9], and nickel [9]. Many of them have been used as catalysts for the polymerization of ethylene [6-9] and the oligomerization of ethylene and propylene to linear and branched products [9]. In 2001, Mashima and coworkers prepared the first rare earth metal 2,5-bis $(N$ aryliminomethyl)pyrrolyl complexes with various aryl substituted ligands [4]. The complexes were synthesized via amine elimination reactions of $\left[\mathrm{Y}\left\{\mathrm{N}\left(\mathrm{SiMe}_{3}\right)_{2}\right\}_{3}\right]$ with the corresponding pyrroles (Scheme 2).

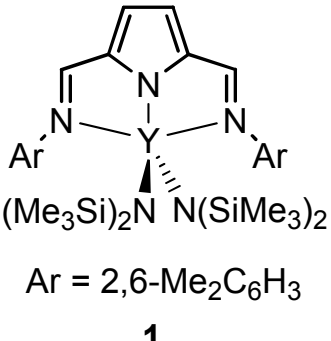

1

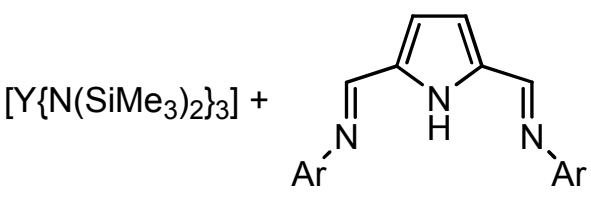

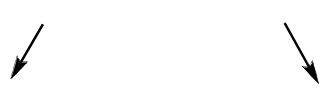

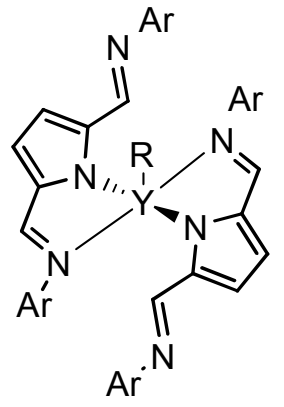

$\mathrm{R}=\mathrm{N}\left(\mathrm{SiMe}_{3}\right)_{2}$ $\mathrm{Ar}=2,6-i \mathrm{Pr}_{2} \mathrm{C}_{6} \mathrm{H}_{3}$

2

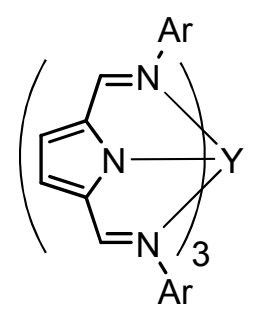

$\mathrm{Ar}=4-\mathrm{MeOC}_{6} \mathrm{H}_{4} \quad 4 \mathrm{a}$ $\mathrm{Ar}=4-\mathrm{MeC}_{6} \mathrm{H}_{4} \quad \mathbf{4 b}$

\section{Scheme 2}


The reaction of the 2,6-dimethylphenyl substituted ligand with $\left[\mathrm{Y}\left\{\mathrm{N}\left(\mathrm{SiMe}_{3}\right)_{2}\right\}_{3}\right]$ led to the mono-substituted complex $\mathbf{1}$ in which the ligand is coordinated by all three nitrogen atoms to the metal center. By using the bulkier 2,6-diisopropylphenyl substituted ligand, the bis(pyrrolyl) complex 2 was formed, in which both pyrrolyl ligands coordinate to the metal center in a bidentate fashion. The reaction of $\left[\mathrm{Y}\left\{\mathrm{N}\left(\mathrm{SiMe}_{3}\right)_{2}\right\}_{3}\right]$ with the 2methylphenyl substituted ligand gave a 4:1 mixture of mono(pyrrolyl) complex 3a and bis(pyrrolyl) complex 3b. The reaction of 4-methoxyphenyl or 4-methylphenyl substituted ligand with $\left[\mathrm{Y}\left\{\mathrm{N}\left(\mathrm{SiMe}_{3}\right)_{2}\right\}_{3}\right]$ afforded the homoleptic tris(pyrrolyl) complexes $\mathbf{4 a}$ and $\mathbf{4 b}$ in which the pyrrolyl ligands are bound in a tridentate fashion to the metal center. The catalytic activities of yttrium complexes $\mathbf{1}, \mathbf{2}, \mathbf{4 a}$ and $\mathbf{4 b}$ were investigated for the polymerization of $\varepsilon$-caprolactone (CL) [4]. The homoleptic pyrrolyl complexes $\mathbf{4 a}$ and $\mathbf{4 b}$ showed no activity, while complexes $\mathbf{1}$ and $\mathbf{2}$ were active catalysts for the polymerization of CL. The polymers obtained with 2 exhibited narrower polydispersities compared with the polymers produced by $\mathbf{1}$. The early investigation showed that 2 containing the steric demanding 2,6-diisopropylphenyl substituted ligand afforded the best catalytic activity. Our new development of the rare earth metal bis(imino)pyrrole complexes has been focused on this ligand system [5].

\subsection{Alkali Metal Compounds}

The rare earth metal complexes are generally synthesized by two methods: salt metathesis and amine or alkane elimination. The preparation of the corresponding alkali metal salts of the ligand is required for salt metathesis reactions. The lithium salt $\left[\left(\mathrm{DIP}_{2} \mathrm{pyr}\right) \mathrm{Li}\right]_{2}(\mathbf{6})$ was first synthesized by Bochmann and coworkers in 2000 via the 
reaction of 2,5-bis $\{N$-(2,6-diisopropylphenyl)iminomethyl $\}$ pyrrole (5) with $n \mathrm{BuLi}$ in toluene (Scheme 3) [9].

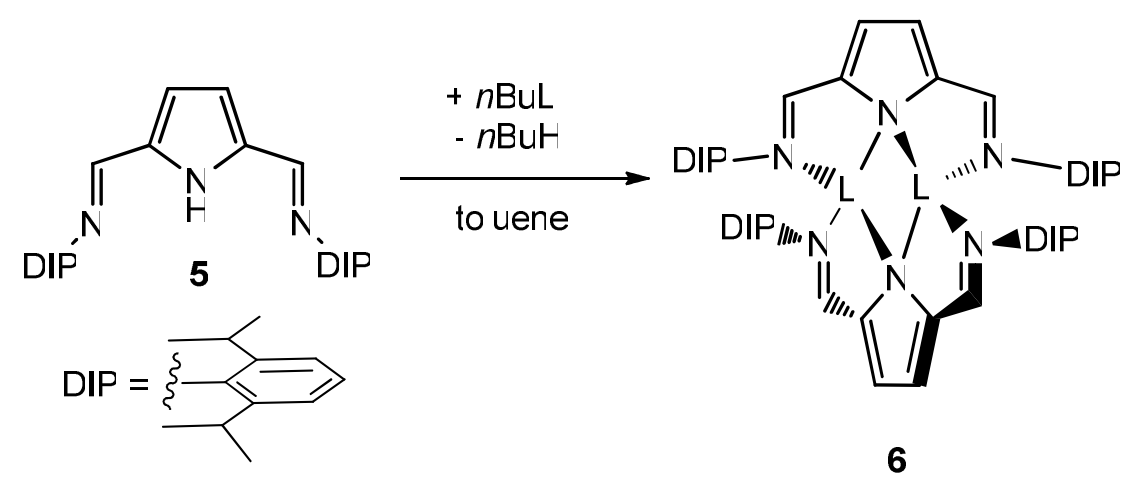

Scheme 3

Treatment of 5 with $\mathrm{NaH}$ or $\mathrm{KH}$ in hot THF afforded [(DIP 2 pyr)M] $(\mathrm{M}=\mathrm{Na}(\mathbf{7}), \mathrm{K}$ (8)) (Scheme 4) [10].

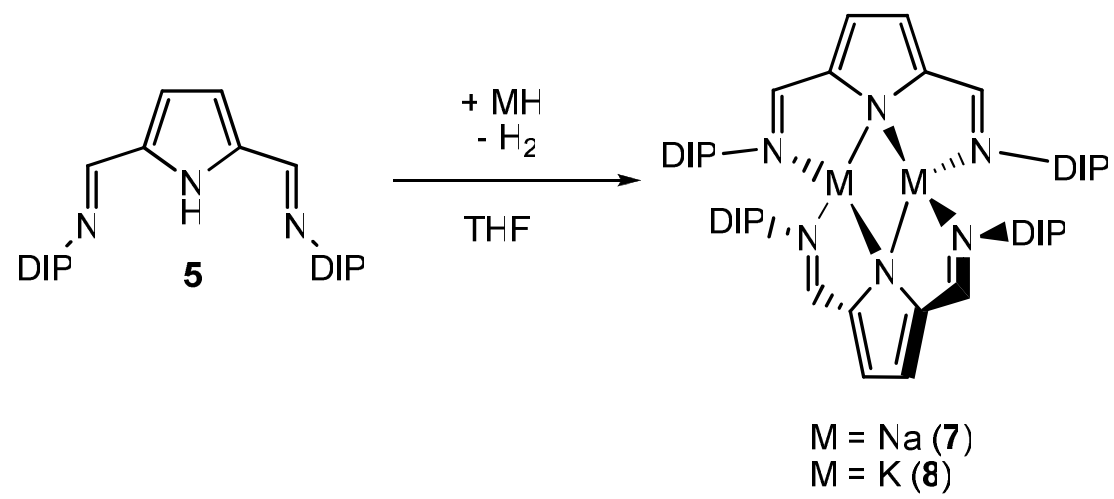

Scheme 4

The solid state structures of complexes 6 and 7 were established by single crystal Xray diffraction and showed a dimeric structure, in which two $\left(\mathrm{DIP}_{2} \mathrm{pyr}\right)^{-}$ligands are 
bridged by two metal atoms, forming a diamond-shaped $\mathrm{M}_{2} \mathrm{~N}_{2}$ core [11]. This structural motif is very rare in lithium chemistry and unknown for sodium compounds [5, 12-14].

\subsection{Rare Earth Metal Complexes}

Whereas the transmetallation of the lithium salt $\mathbf{6}$ with anhydrous yttrium trichloride afforded the "ate"-complex $\mathbf{9}$, the salt metathesis reaction of the potassium salt $\mathbf{8}$ with anhydrous $\mathrm{LnCl}_{3}$ led to the neutral complexes $\left[\left(\mathrm{DIP}_{2} \mathrm{pyr}\right) \mathrm{LnCl}_{2}(\mathrm{THF})_{2}\right](\mathrm{Ln}=\mathrm{Y}(\mathbf{1 0 a}), \mathrm{Lu}$ (10b)) $[10]$ and $\left[\left(\mathrm{DIP}_{2} \mathrm{pyr}\right) \mathrm{NdCl}_{2}(\mathrm{THF})\right]_{2}$ (12) [15] instead (Scheme 5). The solid state structure of neodymium complex $\mathbf{1 2}$ is dimeric, while the chloride complexes of the smaller rare earth metal ions yttrium and lutetium are monomeric. The same product $\left[\left(\mathrm{DIP}_{2}\right.\right.$ pyr $\left.) \mathrm{Y}\left(\mathrm{C}_{5} \mathrm{H}_{5}\right)_{2}\right]$ (11) was produced by the reaction of 2 equiv $\mathrm{Na}\left(\mathrm{C}_{5} \mathrm{H}_{5}\right)$ with either yttrium complex 9 or $\mathbf{1 0 a}$ in THF at room temperature. This seems to indicate that yttrium complexes 9 and 10a have a similar reactivity, regardless of their structural difference. The crystal structures of the complexes $\mathbf{9 , 1 0 a}, \mathbf{1 1}$ and $\mathbf{1 2}$ showed that the $\left(\mathrm{DIP}_{2} \mathrm{pyr}\right)^{-}$ligand coordinates to the yttrium center in a tridentate fashion [5]. 

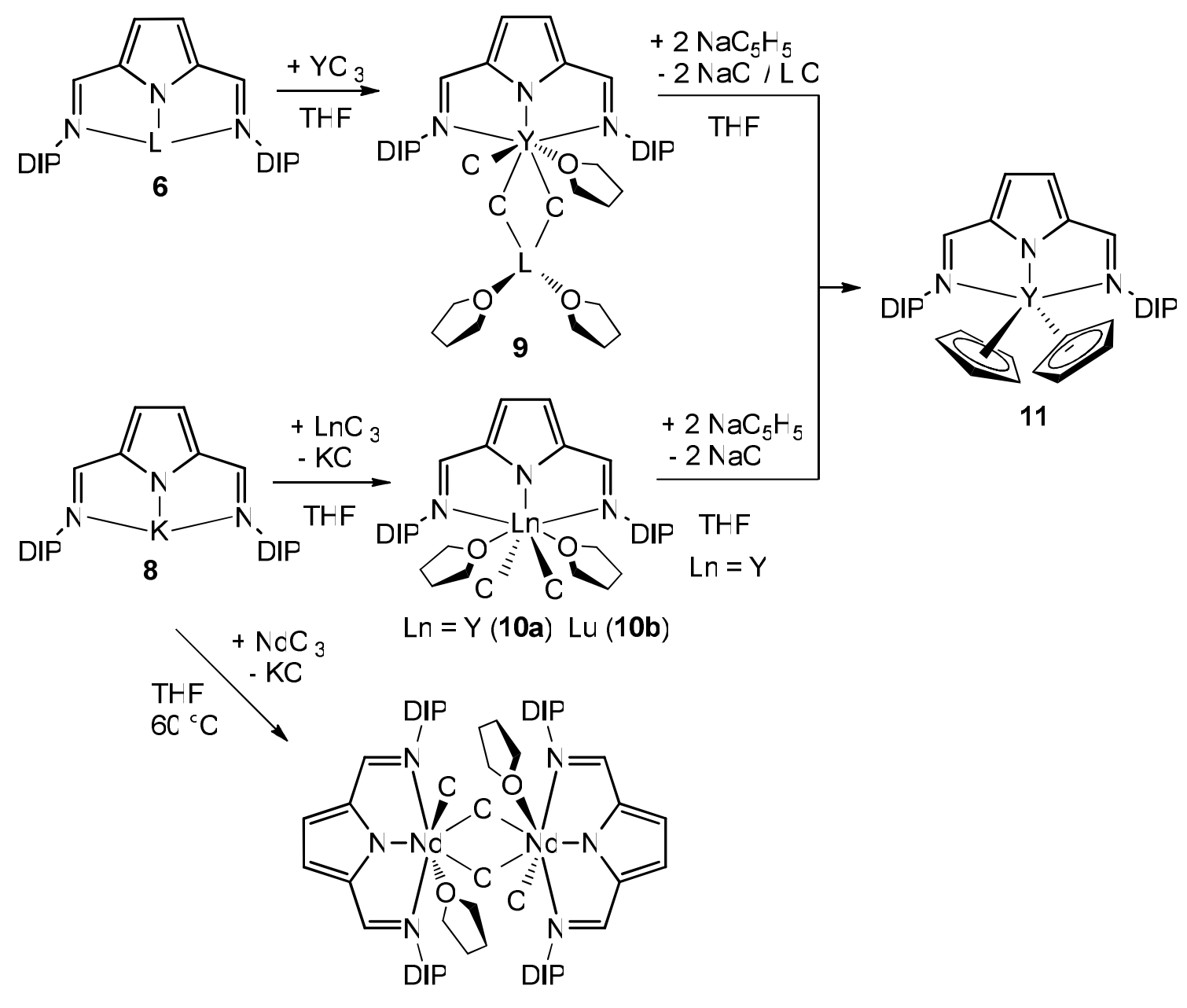

12

\section{Scheme 5}

Many rare earth metal borohydrides and their derivatives were reported as efficient catalysts for the polymerization and copolymerization of styrene [16-18], isoprene $[16,19-22]$ and ethylene $[21,23] .\left[\mathrm{Ln}\left(\mathrm{BH}_{4}\right)_{3}(\mathrm{THF})_{\mathrm{n}}\right]$ is a valuable precursor for preparing rare earth metal borohydride derivatives via salt metathesis reactions with the alkali salt of the corresponding ligand [5]. After the first rare earth metal borohydride complexes of the $\left(\mathrm{DIP}_{2} \mathrm{pyr}\right)^{-}$ligand were prepared in our group in 2009 [24], we have widely developed this catalogue of complexes $[15,25]$. The borohydride complexes $\mathbf{1 3}$ - 
16 were synthesized by reacting 8 with $\left[\mathrm{Ln}\left(\mathrm{BH}_{4}\right)_{3}(\mathrm{THF})_{\mathrm{n}}\right](\mathrm{Ln}=\mathrm{Sc}, \mathrm{n}=2 ; \mathrm{Ln}=\mathrm{La}, \mathrm{Nd}$, $\mathrm{Lu}, \mathrm{n}=3$ ) in $\mathrm{THF}$ at $60{ }^{\circ} \mathrm{C}$. The reaction of 8 with the larger rare earth metal trisborohydrides $\left[\mathrm{Ln}\left(\mathrm{BH}_{4}\right)_{3}(\mathrm{THF})_{3}\right](\mathrm{Ln}=\mathrm{La}, \mathrm{Nd})$ led to $\left[\left(\mathrm{DIP}_{2} \mathrm{pyr}\right) \mathrm{Ln}\left(\mathrm{BH}_{4}\right)_{2}(\mathrm{THF})_{2}\right](\mathrm{Ln}$ $=\mathrm{La}(\mathbf{1 3}), \mathrm{Nd}(\mathbf{1 4}))$. One borohydride ligand was eliminated to form $\mathrm{KBH}_{4}$ as a byproduct (Scheme 6). The single crystal X-ray crystallography of $\mathbf{1 3}$ also confirmed that the $\mathrm{BH}_{4}^{-}$groups are $\eta^{3}$-coordinated. On the contrary, the smaller rare earth metal trisborohydrides $\left[\mathrm{Ln}\left(\mathrm{BH}_{4}\right)_{3}(\mathrm{THF})_{\mathrm{n}}\right](\mathrm{Ln}=\mathrm{Sc}(\mathrm{n}=2), \mathrm{Lu}(\mathrm{n}=3))$ underwent a redox reaction between one $\mathrm{BH}_{4}$-group and one of the Schiff-base functions of the ligand. As a result, a dianionic ligand containing a $\mathrm{N}-\mathrm{BH}_{3}$ unit was formed and coordinates via the amido and the pyrrolyl unit to the metal center. The $\mathrm{N}-\mathrm{BH}_{3}$ unit coordinates in a $\eta^{2}$ fasion via two hydrogen atoms to the metal center. The resulting products $[\{(\mathrm{DIP})(\mathrm{DIP}-$ $\left.\left.\left.\mathrm{BH}_{3}\right) \operatorname{pyr}\right\} \operatorname{Ln}\left(\mathrm{BH}_{4}\right)(\mathrm{THF})_{2}\right](\mathrm{Ln}=\mathrm{Sc}(\mathbf{1 5}), \mathrm{Lu}(\mathbf{1 6}))$ are shown in Scheme 6. During the ligand reduction process, the symmetry of the ligand in $\mathbf{1 5}$ and $\mathbf{1 6}$ was broken. The $\eta^{2}$ coordination mode of the $=\mathrm{N}-\mathrm{BH}_{3}$ moiety and the $\eta^{3}$-coordination mode of the $\mathrm{BH}_{4}{ }^{-}$ ligand in complexes $\mathbf{1 5}$ and $\mathbf{1 6}$ were confirmed in the solid state by single crystal X-ray diffraction as well. To the best of our knowledge, this coordination mode and a comparable reactivity of the $\mathrm{BH}_{4}{ }^{-}$group have not been observed before. We believe that the steric strain resulted from smaller metal center such as scandium and lutetium may cause this unusual redox reactivity $[5,24]$. 


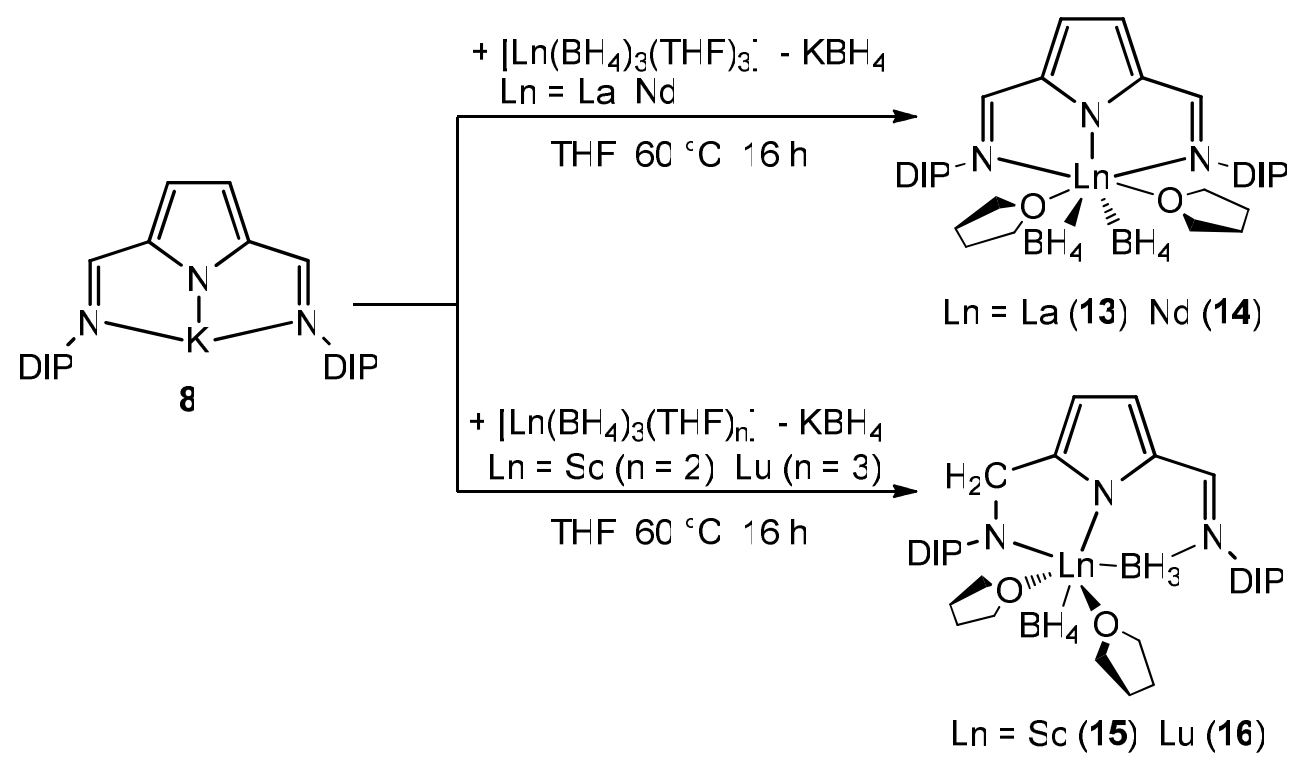

Scheme 6

Mixed borohydride-chloride complexes are unusual in rare earth metal chemistry and were only observed in clusters [26]. Recently, we have prepared two mixed borohydridechloride complexes containing the $\left(\mathrm{DIP}_{2} \mathrm{pyr}\right)^{-}$ligand [15]. The dimeric compounds $\left[\left(\mathrm{DIP}_{2} \mathrm{pyr}\right) \mathrm{LnClBH}_{4}(\mathrm{THF})\right]_{2}(\mathrm{Ln}=\mathrm{La}(\mathbf{1 7}), \mathrm{Nd}(\mathbf{1 8}))$ were synthesized by the reaction of 8 with a 1:1 mixture of the corresponding trisborohydrides $\left[\mathrm{Ln}\left(\mathrm{BH}_{4}\right)_{3}(\mathrm{THF})_{3}\right]$ and anhydrous lanthanide trichlorides in THF at $60{ }^{\circ} \mathrm{C}$ (Scheme 7).

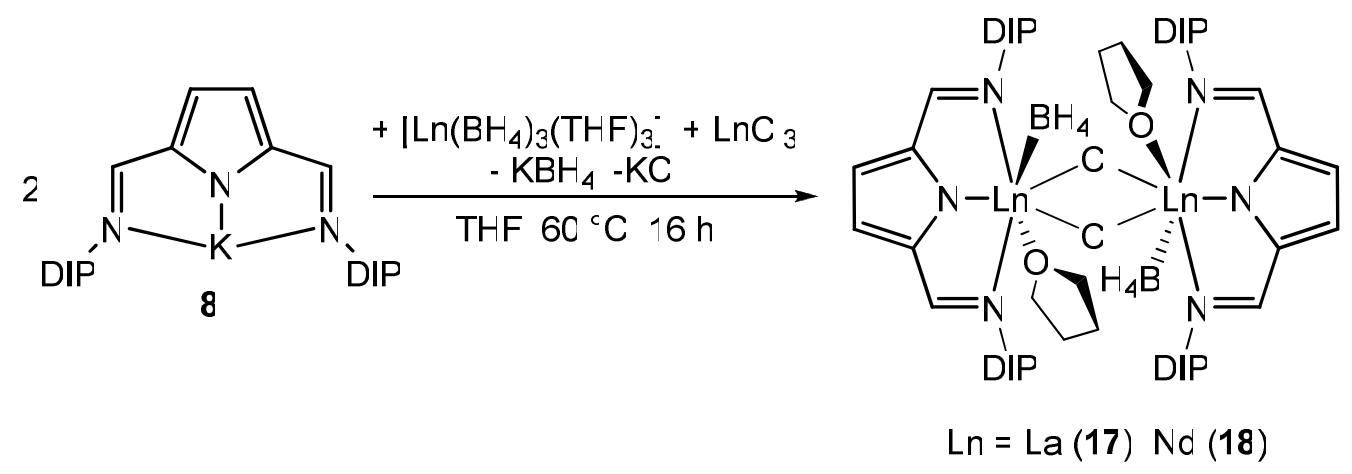

Scheme 7 
The single crystal X-ray diffraction study revealed that both metal complexes are bridged almost symmetrically by two chlorine atoms and the $\mathrm{BH}_{4}{ }^{-}$anions are terminally $\eta^{3}$-coordinated [15].

Neodymium-based Ziegler-Natta systems play a major role in the industrial polymerization of 1,3-butadiene to poly-cis-1,4-butadiene [26-29]. The (DIP 2 pyr) complexes of neodymium, $\quad\left[\left(\mathrm{DIP}_{2} \mathrm{pyr}\right) \mathrm{NdCl}_{2}(\mathrm{THF})\right]_{2} \quad$ (12) and $\left[\left(\mathrm{DIP}_{2} \mathrm{pyr}\right) \mathrm{Nd}\left(\mathrm{BH}_{4}\right)_{2}(\mathrm{THF})_{2}\right]$ (14) were investigated for the polymerization of 1,3 butadiene. The polymerization studies were performed in the presence of $\mathrm{AlEt}_{3} / \mathrm{B}\left(\mathrm{C}_{6} \mathrm{~F}_{5}\right)_{3}$, $\mathrm{AlEt}_{3} /\left[\mathrm{PhNMe}_{2} \mathrm{H}\right]\left[\mathrm{B}\left(\mathrm{C}_{6} \mathrm{~F}_{5}\right)_{4}\right] \quad$ or $\quad \mathrm{MMAO}-3 \mathrm{~A} \quad$ (trimethylaluminum and triisobutylaluminum) as cocatalysts and cyclohexane as solvent at $65^{\circ} \mathrm{C}$. In all reactions, molar ratio of 1,3-butadiene to the catalyst was in the range of 20000 to 22600 . Both complexes exhibited very high activity and good cis-selectivity. By using MMAO-3A as cocatalyst, the chloro compound $\mathbf{1 2}$ showed a five times higher activity than those of the borohydride complex 14. The highest turnover frequency of approximately 19000 (mol of $\mathrm{Nd})^{-1} \mathrm{~h}^{-1}$ was observed for compound 12 by using $\mathrm{AlEt}_{3} / \mathrm{B}\left(\mathrm{C}_{6} \mathrm{~F}_{5}\right)_{3}(7.2 \mathrm{mmol}$ : 100.98 $\mu \mathrm{mol})$ as cocatalyst mixture [25].

\section{Bis(phosphanyl)amide Ligand}

\subsection{Introduction}

An alternative approach for stabilizing highly reactive metal centers is the use of phosphines with P-N bonds [30]. The monoanionic ligands that contain P-N units such as mono(phosphanyl)amide $\left(\mathrm{PPh}_{2} \mathrm{NPh}\right)^{-}$, bis(phosphanyl)amide $\left(\mathrm{PPh}_{2}\right)_{2} \mathrm{~N}^{-} \quad$ and bis(phosphinimino)methanides have become more and more popular in rare earth metal 
chemistry (Scheme 8) [31-35]. In 1999, we prepared the first rare earth metal ate complexes of mono(phosphanyl)amide $\left[\left(\mathrm{PPh}_{2} \mathrm{NPh}\right)_{4} \mathrm{Ln}\right]^{-}(\mathrm{Ln}=\mathrm{Y}, \mathrm{Yb}, \mathrm{Lu})$. The anionic bidentate P-N ligands are coordinated to the metal center in a $\eta^{2}$ fashion. They are also the first homoleptic rare earth metal complexes containing only three-member ring system [36]. $\left(\mathrm{PPh}_{2}\right)_{2} \mathrm{~N}^{-}$has a greater steric demanding than $\left(\mathrm{PPh}_{2} \mathrm{NPh}\right)^{-}$, thus leads to neutral homoleptic complexes. Additionally, the two $\mathrm{PPh}_{2}$ units may allow $\left(\mathrm{PPh}_{2}\right)_{2} \mathrm{~N}^{-}$to act as a dangling ligand in a catalytic transformation [37]. In this report, we only include the results related to $\left(\mathrm{PPh}_{2}\right)_{2} \mathrm{~N}^{-}$ligand.<smiles>O=[N+](c1ccccc1)c1ccccc1</smiles><smiles>c1ccc(P(N=P(c2ccccc2)(c2ccccc2)c2ccccc2)c2ccccc2)cc1</smiles><smiles>[R]N=P(CP(=N[R])(c1ccccc1)c1ccccc1)(c1ccccc1)c1ccccc1</smiles>

\section{Scheme 8}

\subsection{Rare Earth Metal Complexes}

It is well known that the neutral diphosphine amine $\mathrm{NH}\left(\mathrm{PPh}_{2}\right)_{2}[38]$ can be used as a bridging ligand to assemble bi- or polynuclear late transition metal complexes [39-43]. Since we reported the first rare earth metal complexes of $\left(\mathrm{PPh}_{2}\right)_{2} \mathrm{~N}^{-}$in $2002[30,37]$, we have prepared various complexes containing $\left(\mathrm{PPh}_{2}\right)_{2} \mathrm{~N}^{-}$.

As shown in Scheme 9, a series of homoleptic complexes $\left.\left[\left(\mathrm{PPh}_{2}\right)_{2} \mathrm{~N}\right)_{3} \mathrm{Ln}\right](\mathrm{Ln}=\mathrm{Y}(\mathbf{1 9})$, La (20), Nd (21), Er (22), Sm (23), Gd (24), Dy (25)) were obtained via salt or amine elimination followed by crystallization from toluene [37, 44]. The precursor $\left[\mathrm{K}(\mathrm{THF})_{\mathrm{n}}\right]\left[\mathrm{N}\left(\mathrm{PPh}_{2}\right)_{2}\right](\mathrm{n}=1.25,1.5)$ was prepared by treating $\mathrm{NH}\left(\mathrm{PPh}_{2}\right)_{2}$ with $\mathrm{KH}$ in THF. The salt elimination reaction of anhydrous $\mathrm{LnCl}_{3}$ and $\left[\mathrm{K}(\mathrm{THF})_{\mathrm{n}}\right]\left[\mathrm{N}\left(\mathrm{PPh}_{2}\right)_{2}\right]$ in $3: 1$ 
molar ratio in THF led to the complexes 19, 22-25. The amine elimination reaction of $\left[\operatorname{Ln}\left\{\mathrm{N}\left(\mathrm{SiMe}_{3}\right)_{2}\right\}_{3}\right]$ and 3 equiv of $\mathrm{NH}\left(\mathrm{PPh}_{2}\right)_{2}$ afforded the complexes 19-21, 23. The single X-ray structure showed that the complexes $\mathbf{1 9 - 2 5}$ are iso-structural. Three $\eta^{2}$ $\left(\mathrm{PPh}_{2}\right)_{2} \mathrm{~N}^{-}$ligands are coordinated to a metal center in a trigonal prismatic geometry. Within the ligand the P-N bond distance varies significantly. The ${ }^{31} \mathrm{P}$ NMR data shows a dynamic behavior of the ligand in solution. This is caused by rapid exchange of the two different phosphorus atoms [37, 44]. The lutetium complex 26 was prepared by the salt elimination in THF followed by crystallization in THF/pentane (Scheme 9). The solid state structure of $\mathbf{2 6}$ reveals a seven coordination sites around the lutetium center. Other than six coordination sites are occupied by three ligands, the seventh is by a THF molecule. This result suggests the $\left(\mathrm{PPh}_{2}\right)_{2} \mathrm{~N}^{-}$ligand is flexible in its coordination behavior [37].

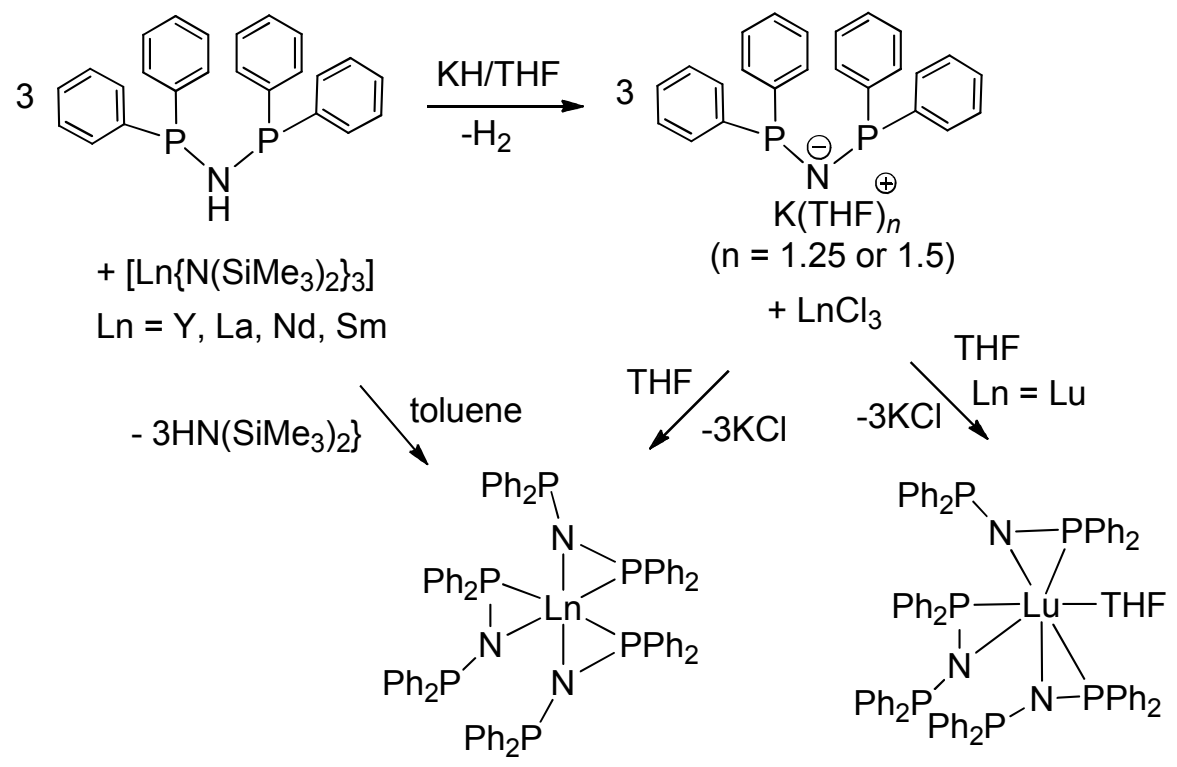
$\operatorname{Ln}=Y(19), \operatorname{La}(20), \operatorname{Nd}(21), \operatorname{Er}(22)$, Sm (23), Gd (24), Dy (25)

\section{Scheme 9}


The homoleptic $\left(\mathrm{PPh}_{2}\right)_{2} \mathrm{~N}^{-}$ligand rare earth metal complexes 19-22 have been investigated for the polymerization of CL. All the complexes are highly active catalysts for the polymerization of CL at room temperature. With molar monomer/initiator ration of 150/1, 19-22 afforded corresponding polycaprolactone (PCL, $\left.M_{\mathrm{n}}=17200-26200\right)$ in 95-99 \% yields within 1 min. Moderate polydispersity $M_{\mathrm{w}} / M_{\mathrm{n}}(1.58-1.83)$ was observed with catalysts 19, 20 and 22. The neodymium complex 21 showed remarkable narrow polydispersity $\left(M_{\mathrm{w}} / M_{\mathrm{n}}=1.12\right)$. Based on the crystal structure of seven coordination complex 26, we propose the initial step of CL polymerization is the lactone insertion to the lanthanide atom to form a seven coordination sphere around the central atom [37].

In order to further study the coordination behavior and the steric demanding of the $\left(\mathrm{PPh}_{2}\right)_{2} \mathrm{~N}^{-}$ligand, we prepared different categories of complexes, which contained one or two $\left(\mathrm{PPh}_{2}\right)_{2} \mathrm{~N}^{-}$groups.

The first heteroleptic $\left(\mathrm{PPh}_{2}\right)_{2} \mathrm{~N}^{-}$ligand lanthanide complex $\left[\mathrm{Cp}^{*}{ }_{2} \mathrm{Sm}\left\{\left(\mathrm{PPh}_{2}\right)_{2} \mathrm{~N}\right\}\right]\left(\mathrm{Cp}^{*}\right.$ $\left.=\eta^{5}-\mathrm{C}_{5} \mathrm{Me}_{5}\right)(27)$ was prepared via the salt elimination reaction of anhydrous $\mathrm{SmCl}_{3}$ and $\left[\mathrm{K}(\mathrm{THF})_{\mathrm{n}}\right]\left[\mathrm{N}\left(\mathrm{PPh}_{2}\right)_{2}\right]$ followed by an addition of $\mathrm{KCp}^{*}$ (Scheme 10) [45].

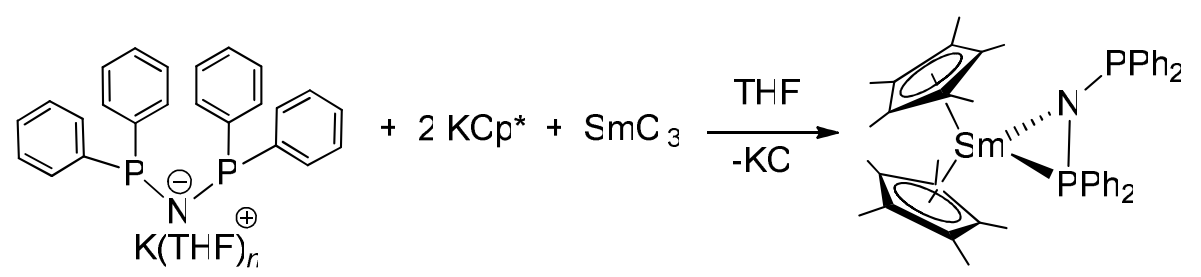

27

\section{Scheme 10}


The chloride complexes $\mathbf{2 8 - 3 1}$ containing mono substitute ligand were prepared by the salt elimination reaction of anhydrous $\mathrm{LnCl}_{3}$ and $\left[\mathrm{K}(\mathrm{THF})_{\mathrm{n}}\right]\left[\mathrm{N}\left(\mathrm{PPh}_{2}\right)_{2}\right](\mathrm{Scheme} 11)$. The solid state structures of these complexes show a distorted pentagonal bipyramidal geometry, in which chlorine atoms are located in the apical positions [46].

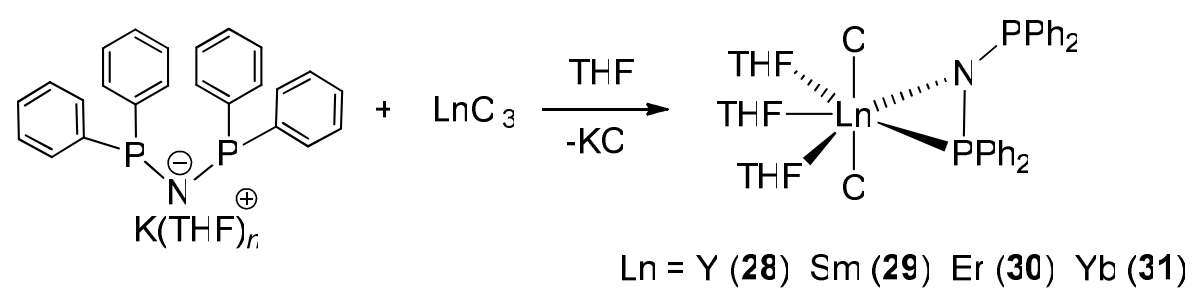

\section{Scheme 11}

The cyclooctatetraene complexes $\mathbf{3 2}$ and $\mathbf{3 3}$ can be obtained either by the reaction of the samarium mono ligand chloride complex 29 and $\mathrm{K}_{2} \mathrm{C}_{8} \mathrm{H}_{8}$ or by the reaction of [ $\operatorname{Ln}\left(\eta^{8}-\right.$ $\left.\left.\mathrm{C}_{8} \mathrm{H}_{8}\right)(\mathrm{THF})_{3} \mathrm{I}\right]$ and $\left[\mathrm{K}(\mathrm{THF})_{\mathrm{n}}\right]\left[\mathrm{N}\left(\mathrm{PPh}_{2}\right)_{2}\right]($ Scheme 12). The single crystal X-ray structure revealed that both complexes $\mathbf{3 2}$ and $\mathbf{3 3}$ adopt a four-legged piano-stool conformation [46].

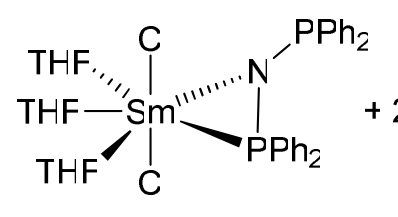

29

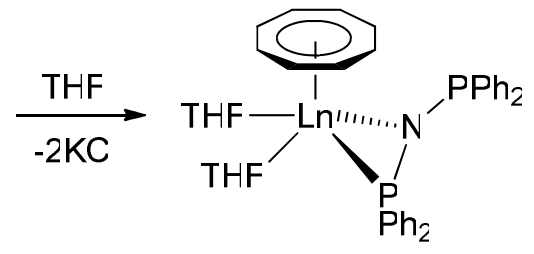

$\mathrm{Ln}=\mathrm{La}(32) \mathrm{Sm}(33)$<smiles>FC1([Te](F)(I)(I)(I)I)C=CC=CC1</smiles>

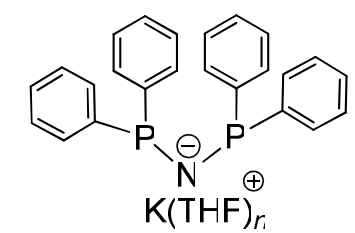

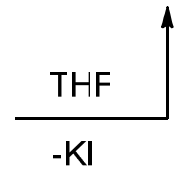

\section{Scheme 12}


The more soluble bistrimethylsilyl cyclooctatetrene complex 34 was prepared by the reaction of $\mathrm{Li}_{2}\left[1,4-\left(\mathrm{Me}_{3} \mathrm{Si}\right)_{2} \mathrm{C}_{8} \mathrm{H}_{6}\right]$ with anhydrous $\mathrm{YCl}_{3}$ in $\mathrm{THF}$ followed by an addition of $\left[\mathrm{K}(\mathrm{THF})_{\mathrm{n}}\right]\left[\mathrm{N}\left(\mathrm{PPh}_{2}\right)_{2}\right]\left(\right.$ Scheme 13). A triplet in the ${ }^{89} \mathrm{Y}$ NMR suggests the phosphorus atoms are chemically equivalent in solution [46].

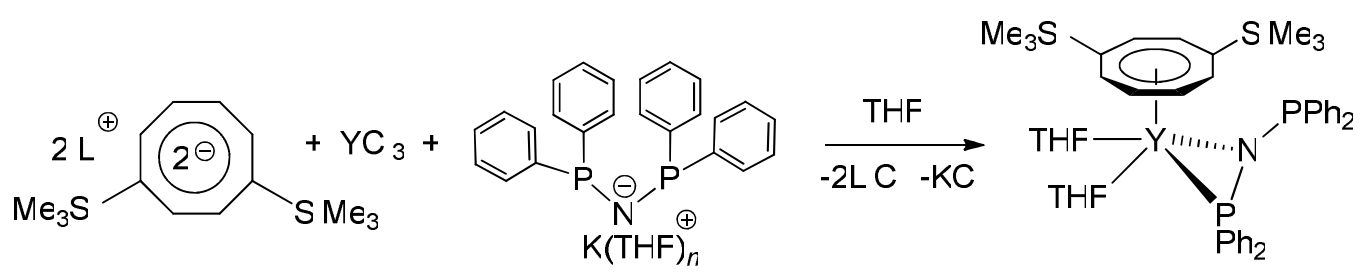

34

\section{Scheme 13}

Several mixed potassium-lanthanide complexes with an interesting wheel-shaped structure were obtained from the one pot reaction of anhydrous $\mathrm{LnCl}_{3}$, $\left[\mathrm{K}(\mathrm{THF})_{\mathrm{n}}\right]\left[\mathrm{N}\left(\mathrm{PPh}_{2}\right)_{2}\right], \quad \mathrm{NaC}_{5} \mathrm{H}_{5} \quad$ and $\mathrm{KNPh}_{2} \quad$ in $\quad$ THF. $\quad\left[\mathrm{CpLn}\left(\mathrm{NPh}_{2}\right)_{2}-\right.$ $\left.\left\{\mathrm{N}\left(\mathrm{PPh}_{2}\right)_{2}\right\}_{2} \mathrm{~K}_{2}(\mathrm{THF})_{4}\right]_{2}\left(\mathrm{Cp}=\eta^{5}-\mathrm{C}_{5} \mathrm{H}_{5}\right)(\mathrm{Ln}=\operatorname{Er}(\mathbf{3 5 a}), \mathrm{Yb}(\mathbf{3 5 b}))$ are hexanuclear coordination oligomers (Scheme 14), while $\left[\mathrm{CpSm}\left(\mathrm{NPh}_{2}\right)_{2}\left\{\left(\mathrm{~N}\left(\mathrm{PPh}_{2}\right)_{2}\right)_{2}\right\} \mathrm{K}\right]_{\mathrm{m}}$ (36) is an octanuclear coordination polymer (Scheme 15). These unusual complexes were formed as a result of the insufficient shielding of the lanthanide atom by the small ligands. These metallate complexes are connected to each other via the potassium ions. The potassium cations bridge the metallate units via $\pi$-coordination to the aromatic rings from the ligands, thus forming wheel-shaped oligomers and polymers. The shape of the "wheel" appears to depend on the lanthanide ionic radius [47]. 


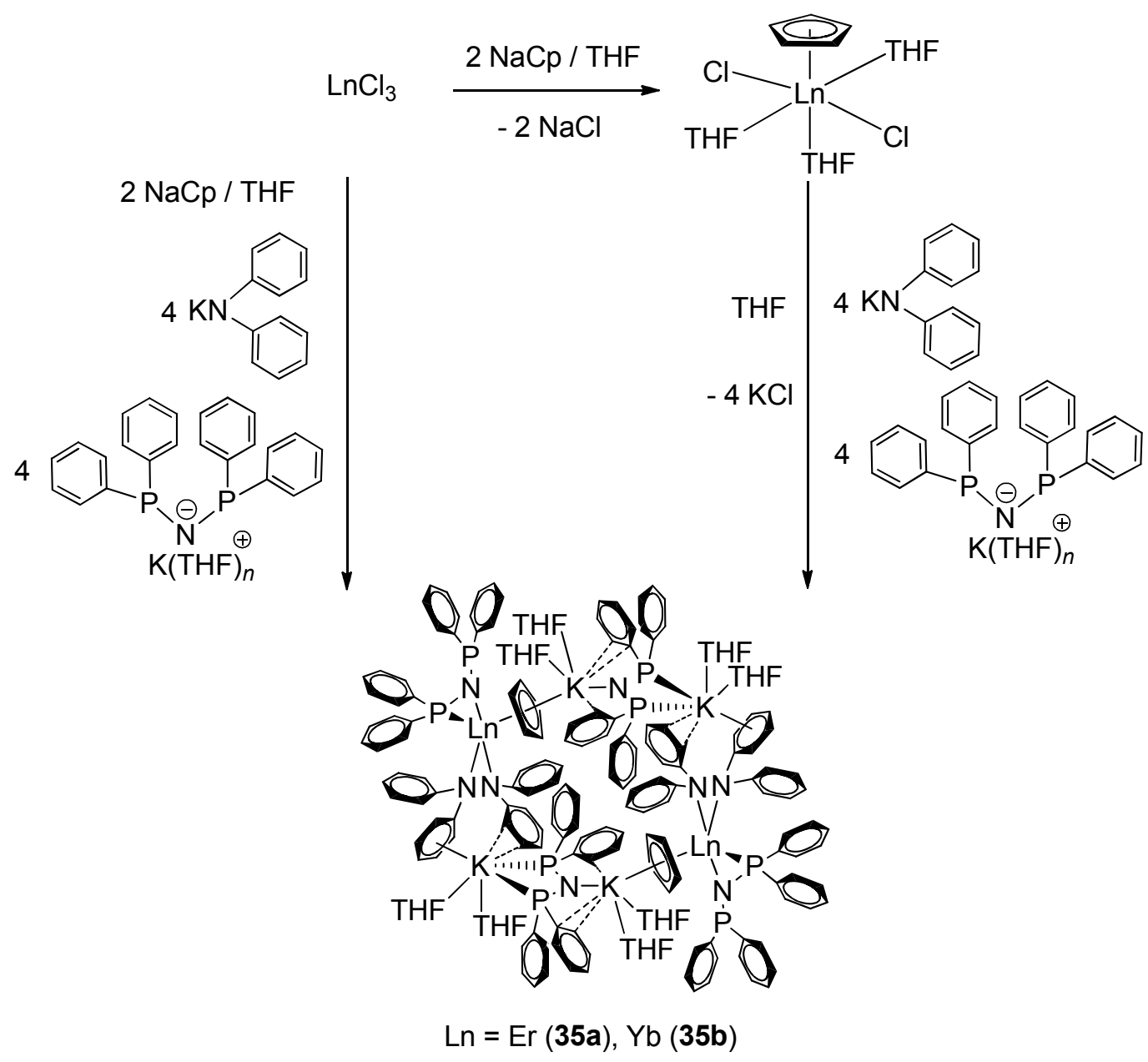

Scheme 14 


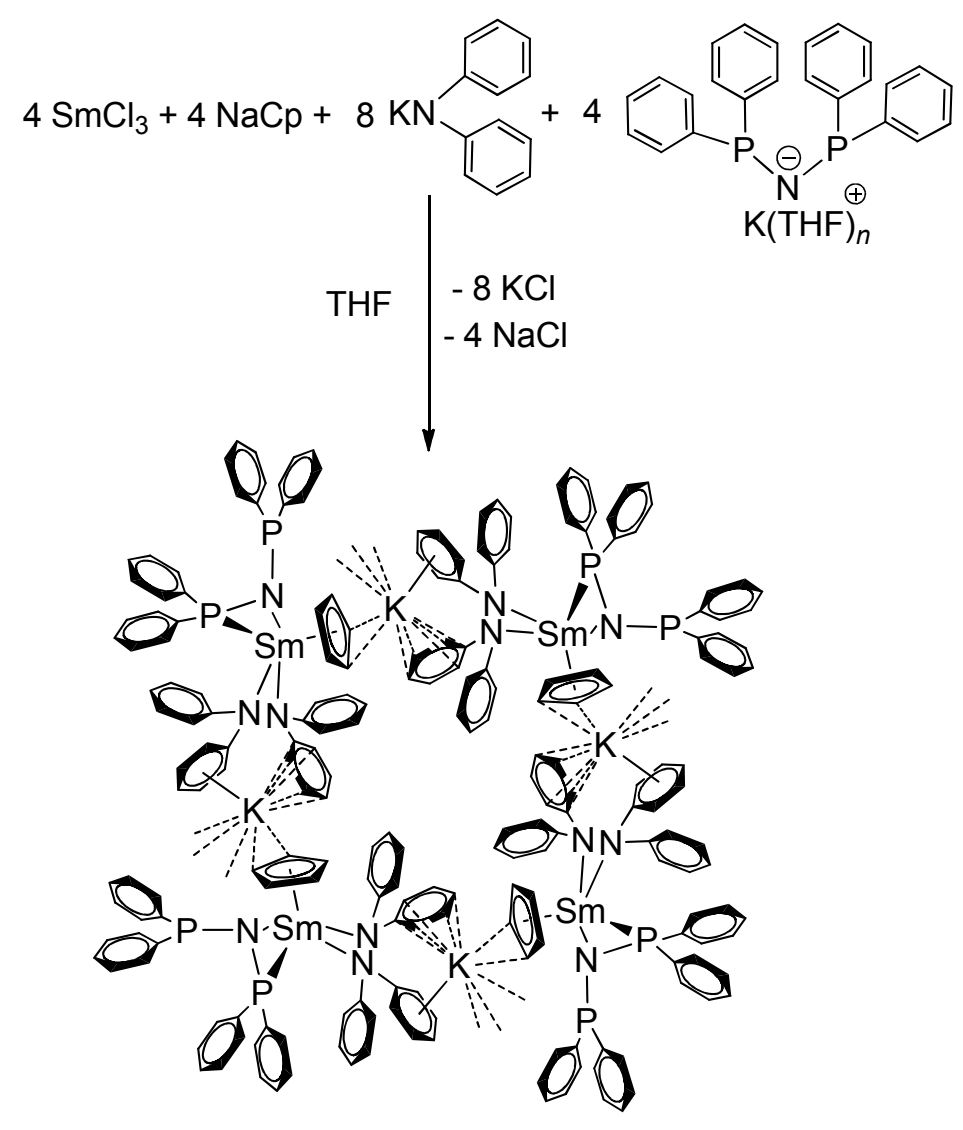

36

\section{Scheme 15}

In 2004, we reported several bis $\left(\mathrm{PPh}_{2}\right)_{2} \mathrm{~N}^{-}$ligand substitute rare earth metal complexes. $\left[\left\{\left(\mathrm{PPh}_{2}\right)_{2} \mathrm{~N}\right\}_{2} \mathrm{Yb}(\mathrm{THF})_{2} \mathrm{Cl}\right](37)$ was synthesized by the reaction of $\mathrm{YbCl}_{3}$ and a slightly excess of $\left[\mathrm{K}(\mathrm{THF})_{n}\right]\left[\mathrm{N}\left(\mathrm{PPh}_{2}\right)_{2}\right]$ in THF. Further reacting 37 with KCp*afforded $\left[\left\{\left(\mathrm{PPh}_{2}\right)_{2} \mathrm{~N}\right\}_{2} \mathrm{YbCp} *\right]$ (38) $\left.\left.(\text { Scheme 16). [\{(PPh})_{2} \mathrm{~N}\right\}_{2} \mathrm{SmCp}(\mathrm{THF})\right](39)$ was obtained by treating $\left[\mathrm{CpSmCl}_{2}(\mathrm{THF})_{2}\right]$ with 2 equiv of $\left[\mathrm{K}(\mathrm{THF})_{\mathrm{n}}\right]\left[\mathrm{N}\left(\mathrm{PPh}_{2}\right)_{2}\right]$ in $\mathrm{THF}$ (Scheme 17). A similar coordination of one THF molecule in $\left[\mathrm{Cp}_{3} \mathrm{Sm}(\mathrm{THF})\right]$ indicates that the steric demand of $\left(\mathrm{PPh}_{2}\right)_{2} \mathrm{~N}^{-}$ligand is similar to $\mathrm{Cp}$ ring [48]. 


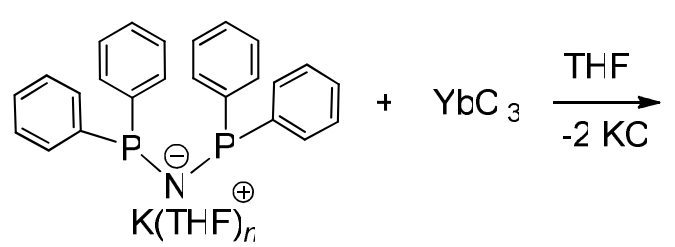

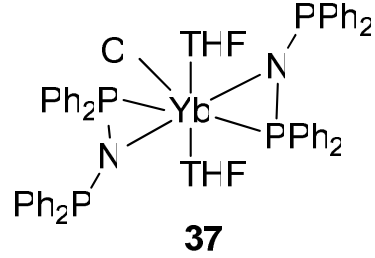

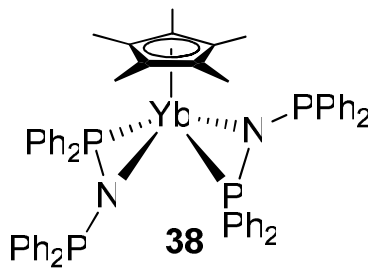

\section{Scheme 16}

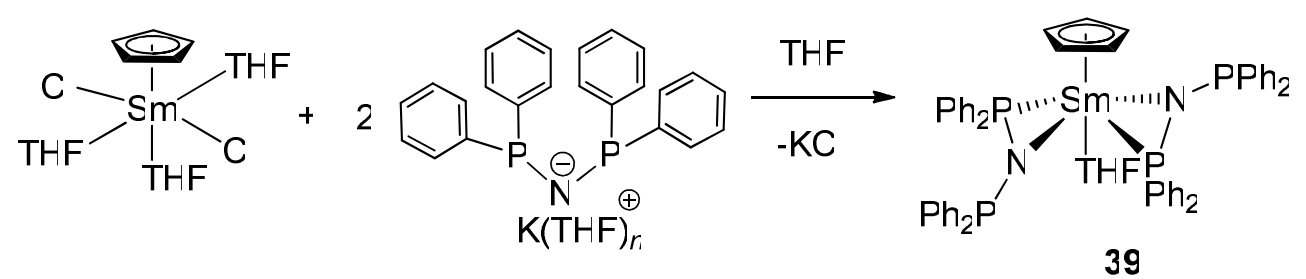

\section{Scheme 17}

Recently we have applied the $\left(\mathrm{PPh}_{2}\right)_{2} \mathrm{~N}^{-}$ligand to divalent lanthanide complexes. $\left[\left\{\left(\mathrm{PPh}_{2}\right)_{2} \mathrm{~N}\right\}_{2} \mathrm{Ln}(\mathrm{THF})_{3}\right](\mathrm{Ln}=\mathrm{Yb}(\mathbf{4 0}), \mathrm{Eu}(\mathbf{4 1}))$ were prepared by the salt elimination reaction of $\mathrm{LnI}_{2}$ and 2 equiv of $\left[\mathrm{K}(\mathrm{THF})_{\mathrm{n}}\right]\left[\mathrm{N}\left(\mathrm{PPh}_{2}\right)_{2}\right]$ in $\mathrm{THF}$ (Scheme 18) $[49,50]$.<smiles>N#CP(c1ccccc1)P(c1ccccc1)c1ccccc1</smiles>

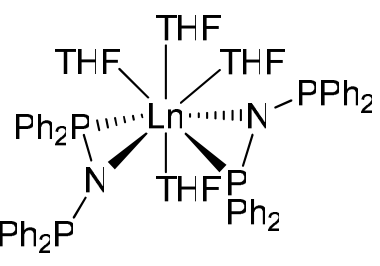

$$
\operatorname{Ln}=\mathrm{Yb}(\mathbf{4 0}) \mathrm{Eu}(\mathbf{4 1})
$$

\section{Scheme 18}


The solid state structure of the rare earth metal complexes containing the $\left(\mathrm{PPh}_{2}\right)_{2} \mathrm{~N}^{-}$ group shows that the bidentate P-N ligand always coordinates to the metal center in a $\eta^{2}$ fashion.

\section{Conclusion}

Three types of $\left(\mathrm{DIP}_{2} \mathrm{pyr}\right)^{-}$ligand rare earth metal complexes including chlorides, borohydrides, and mixed borohydride chloride were successfully prepared and fully characterized. The borohydride complexes are the first examples of rare earth metals borohydride complexes containing the $\left(\mathrm{DIP}_{2} \mathrm{pyr}\right)^{-}$ligand. An unusual redox reaction of a $\mathrm{BH}_{4}{ }^{-}$anion with the Schiff-base function of the ligand was observed for the smaller rare earth metal complexes. As product $\left[\left\{(\mathrm{DIP})\left(\mathrm{DIP}-\mathrm{BH}_{3}\right) \operatorname{pyr}\right\} \mathrm{Ln}\left(\mathrm{BH}_{4}\right)(\mathrm{THF})_{2}\right](\mathrm{Ln}=\mathrm{Sc}, \mathrm{Lu})$ with a new coordination mode was isolated. In addition, the two neodymium complexes 12 and 14 were investigated as Ziegler-Natta catalysts for the polymerization of 1,3butadiene to form poly-cis-1,4-butadiene with various cocatalysts. High activity and good selectivity were achieved by using the chloride complex 12.

Mono-, bis- and tris- $\left(\mathrm{PPh}_{2}\right)_{2} \mathrm{~N}^{-}$ligand rare earth metal complexes were successfully prepared and characterized. The bidentate P-N ligand coordinates to the metal center in a $\eta^{2}$ fashion in all the cases. The homoleptic tris- $\left(\mathrm{PPh}_{2}\right)_{2} \mathrm{~N}^{-}$ligand complexes 19-22 are highly active catalysts for the polymerization of CL. The neodymium complex 21 showed remarkable narrow polydispersity. 


\section{Acknowledgement}

This work was supported by the Deutsche Forschungsgemeinschaft (DFG Schwerpunktprogramm (SPP 1166): Lanthanoidspezifische Funktionalitäten in Molekül und Material.

\section{Refernces}

[1] F. T. Edelmann, Angew. Chem. Int. Ed. 1995, 34, 2466-2488.

[2] F. T. Edelmann, D. M. M. Freckmann, H. Schumann, Chem. Rev. 2002, 102, 1851-1896.

[3] K. Mashima, H. Tsurugi, J. Organomet. Chem. 2005, 690, 4414-4423.

[4] Y. Matsuo, K. Mashima, K. Tani, Organometallics 2001, 20, 3510-3518.

[5] J. Jenter, PhD thesis, Karlsruher Institute of Technologie (KIT) (Karlsruhe), 2010.

[6] Y. Matsuo, H. Tsurugi, T. Yamagata, K. Tani, K. Mashima, Bull. Chem. Soc. Jpn. 2003, 76, 1965-1968.

[7] H. Tsurugi, Y. Matsuo, T. Yamagata, K. Mashima, Organometallics 2004, 23, 2797-2805.

[8] B. A. Salisbury, J. F. Young, G. P. A. Yap, K. H. Theopold, Collect. Czech. Chem. Commun. 2007, 72, 637-648.

[9] D. M. Dawson, D. A. Walker, M. Thornton-Pett, M. Bochmann, Dalton Trans. 2000, 459-466.

[10] N. Meyer, M. Kuzdrowska, P. W. Roesky, Eur. J. Inorg. Chem. 2008, 1475-1479.

[11] J. Jenter, P. W. Roesky, New J. Chem. 2010, DOI:10.1039/B1039NJ00651F. 
[12] P.-C. Kuo, J.-C. Chang, W.-Y. Lee, H. M. Lee, J.-H. Huang, J. Organomet. Chem. 2005, 690, 4168-4174.

[13] S. J. Trepanier, S. Wang, Organometallics 1993, 12, 4207-4210.

[14] G. L. J. v. Vliet, F. J. J. d. Kanter, M. Schakel, G. W. Klumpp, A. L. Spek, M. Lutz, Chem. Eur. J. 1999, 5, 1091-1094.

[15] J. Jenter, R. Köppe, P. W. Roesky, C. R. Chimie 2010, DOI:10.1016/j.ctci.2009.1011.2003.

[16] M. Visseaux, M. Mainil, M. Terrier, A. Mortreux, P. Roussel, T. Mathivet, M. Destarac, Dalton Trans. 2008, 4558-4561.

[17] P. Zinck, A. Valente, A. Mortreux, M. Visseaux, Polymer 2007, 48, 4609-4614.

[18] P. Zinck, M. Visseaux, A. Mortreux, Z. Anorg. Allg. Chem. 2006, 632, 19431944.

[19] F. Bonnet, C. D. C. Violante, P. Roussel, A. Mortreux, M. Visseaux, Chem. Commun. 2009, 3380-3382.

[20] F. Bonnet, M. Visseaux, D. Barbier-Baudry, E. Vigier, M. M. Kubicki, Chem. Eur. J. 2004, 10, 2428-2434.

[21] M. Visseaux, T. Chenal, P. Roussel, A. Mortreux, J. Organomet. Chem. 2006, 691, 86-92.

[22] M. Terrier, M. Visseaux, T. Chenal, A. Mortreux, J. Polym. Sci., Part A: Polym. Chem. 2007, 45, 2400-2409.

[23] J. Thuilliez, R. Spitz, C. Boisson, Macromol. Chem. Phys. 2006, 207, 1727-1731.

[24] N. Meyer, J. Jenter, P. W. Roesky, G. Eickerling, W. Scherer, Chem. Commun. 2009, 4693-4695. 
[25] J. Jenter, N. Meyer, P. W. Roesky, S. K.-H. Thiele, G. Eickerling, W. Scherer, Chem. Eur. J. 2010, 16, accepted.

[26] R. Taube, G. Sylvester, in Applied Homogeneous Catalysis with Organometallic Compounds (2nd Ed.), VCH, Weinheim, 2002, pp. 285-315.

[27] D. J. Wilson, Polym. Int. 1996, 39, 235-242.

[28] J. Witte, Angew. Makromol. Chem. 1981, 94, 119-146.

[29] A. Fischbach, R. Anwander, Adv. Polym. Sci. 2006, 204, 155-281.

[30] P. W. Roesky, Heteroat. Chem 2002, 13, 514-520.

[31] A. Recknagel, A. Steiner, M. Noltemeyer, S. Brooker, D. Stalke, F. T. Edelmann, J. Organomet. Chem. 1991, 414, 327-335.

[32] T. G. Wetzel, S. Dehnen, P. W. Roesky, Angew. Chem. 1999, 111, 1155-1158.

[33] U. Reißmann, P. Poremba, M. Noltemeyer, H.-G. Schmidt, F. T. Edelmann, Inorg. Chim. Acta 2000, 303, 156-162.

[34] S. Wingerter, M. Pfeiffer, F. Baier, T. Stey, D. Stalke, Z. Anorg. Allg. Chem. 2000, 626, 1121-1130.

[35] M. T. Gamer, P. W. Roesky, J. Organomet. Chem. 2002, 647, 123-127.

[36] T. G. Wetzel, S. Dehnen, P. W. Roesky, Angew. Chem. Int. Ed. 1999, 38, 10861088.

[37] P. W. Roesky, M. T. Gamer, M. Puchner, A. Greiner, Chem. Eur. J. 2002, 8, $5265-5271$.

[38] P. Bhattacharyya, J. D. Woollins, Polyhedron 1995, 14, 3367-3388.

[39] I. Bachert, I. Bartusseck, P. Braunstein, E. Guillon, J. Rose, G. Kickelbick, J. Organomet. Chem. 1999, 588, 143-151. 
[40] J. Blin, P. Braunstein, J. Fischer, G. Kickelbick, M. Knorr, X. Morise, T. Wirth, J. Chem. Soc., Dalton Trans. 1999, 2159-2170.

[41] P. Braunstein, J. Cossy, M. Knorr, C. Strohmann, P. Vogel, New J. Chem. 1999, 23, 1215-1222.

[42] P. Braunstein, J. Durand, G. Kickelbick, M. Knorr, X. Morise, R. Pugin, A. Tiripicchio, F. Ugozzoli, J. Chem. Soc., Dalton Trans. 1999, 4175-4186.

[43] M. Knorr, C. Strohmann, Organometallics 1999, 18, 248-257.

[44] M. T. Gamer, M. Rästatter, P. W. Roesky, Inorg. Chim. Acta 2005, 358, 41724176.

[45] M. T. Gamer, G. Canseco-Melchor, P. W. Roesky, Z. Anorg. Allg. Chem. 2003, $629,2113-2116$.

[46] P. W. Roesky, M. T. Gamer, N. Marinos, Chem. Eur. J. 2004, 10, 3537-3542.

[47] M. T. Gamer, P. W. Roesky, Inorg. Chem. 2005, 44, 5963-5965.

[48] M. T. Gamer, P. W. Roesky, Inorg. Chem. 2004, 43, 4903-4906.

[49] T. K. Panda, M. T. Gamer, P. W. Roesky, Inorg. Chim. Acta 2006, 359, 47654768.

[50] P. W. Roesky, Inorg. Chem. 2006, 45, 798-802. 


\section{Biographical Sketch}

Peter W. Roesky was born in Göttingen, Germany, in 1967. He obtained his diploma in 1992 from the University of Würzburg and his doctoral degree from the Technical University of Munich (with Prof. W. A. Herrmann) in 1994. He was as a postdoc with Prof. T. J. Marks at Northwestern University (1995-1996). In 1999 he completed his Habilitation at the University of Karlsruhe under the guidance of Prof. D. Fenske. As a full professor he joined the faculty of the Freie Universität Berlin in 2001. Since 2008 he holds the chair for inorganic functional material at the University of Karlsruhe. He received in 1996 a Liebig-Stipendium of the Fonds der Chemischen Industrie, in 1999 a Heisenberg-Stipendium, and in 2000 a Karl-Winnacker-Stipendium. His current research interest is focused on the synthesis of inorganic and organometallic compounds of the lanthanides, gold, zinc, and the alkaline earth elements for catalytic applications and for material science.

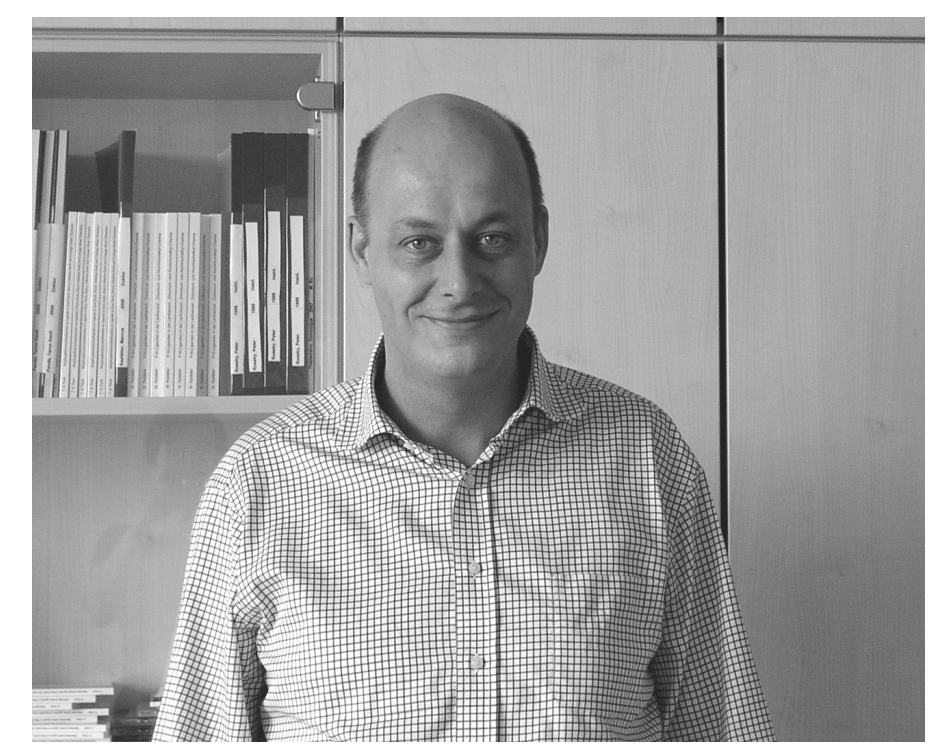




\title{
Entry for the Table of Contents
}

\begin{abstract}
Rare earth element complexes having the very bulky 2,5-bis $\{N-(2,6-$ diisopropylphenyl)iminomethyl pyrrolyl, and the sterically less demanding bis(phosphanyl)amide ligand, $\left(\mathrm{PPh}_{2}\right)_{2} \mathrm{~N}^{-}$, in the coordination sphere are reviewed.
\end{abstract}
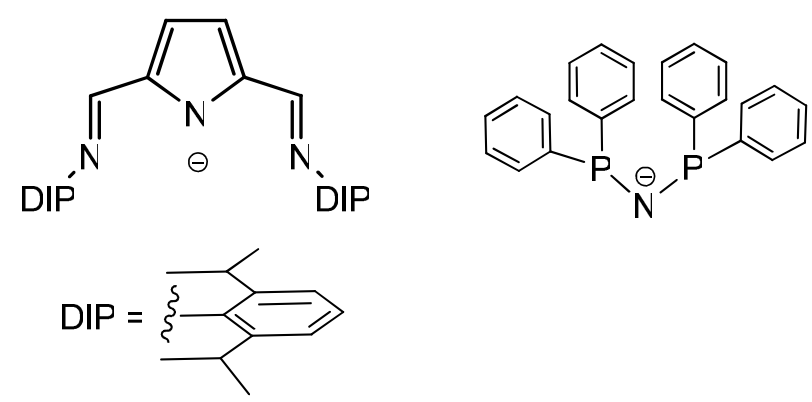
COPYRIGHT TRANSFER AGREEMENT

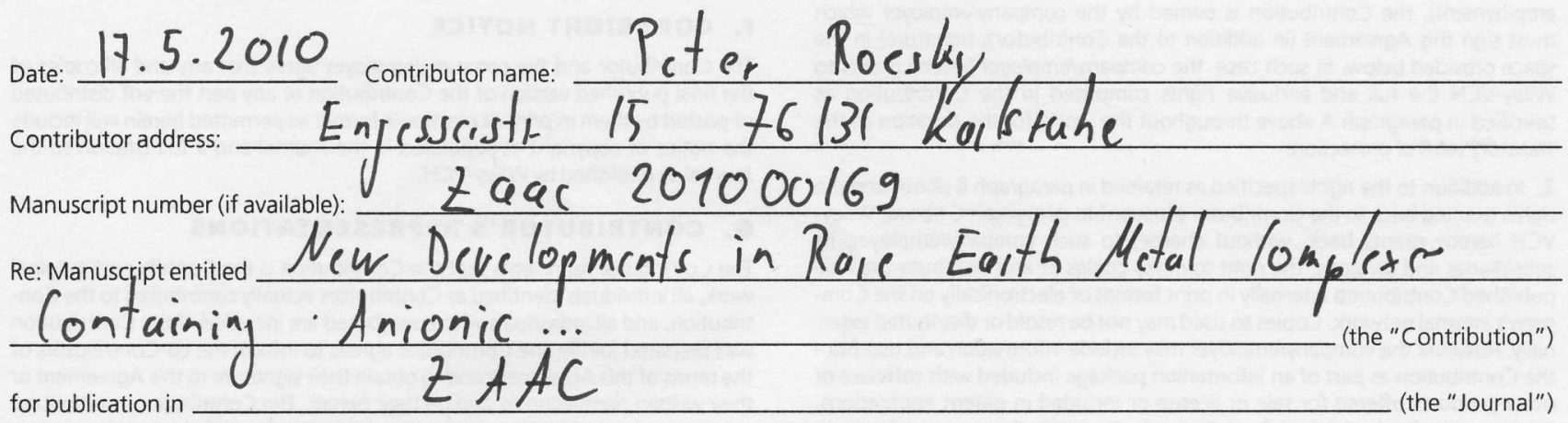

published by Wiley-VCH Verlag GmbH \& Co. KGaA ("Wiley-VCH").

Dear Contributor(s):

Thank you for submitting the Contribution for publication. In order to expedite the editing and publishing process and enable Wiley-VCH to disseminate the Contribution to the fullest extent, we need to have this Copyright Transfer Agreement signed and returned as directed in the Journal's instructions for authors as soon as possible. If the Contribution is not accepted for publication, or if the Contribution is subsequently rejected, this Agreement shall be null and void. Publication cannot proceed without a signed copy of this Agreement.

\section{A. RIGHTS GRANTED}

1. The Contributor hereby grants to Wiley-VCH for the duration of the statutory term of copyright protection, the full and exclusive rights comprised in the Contribution including but not limited to the right to publish, republish, transmit, sell, distribute, store and process in electronic media of any kind, include in document delivery services and otherwise use the Contribution in whole or in part in electronic and print editions of the Journal and in derivative works throughout the world, in all languages and in all media of expression now known or later developed, and to license or permit others to do so.

2. Reproduction, posting, transmission or other distribution or use of the final Contribution in whole or in part in any medium by the Contributor as permitted by this Agreement requires a citation to the Journal and an appropriate credit to Wiley-VCH as Publisher, suitable in form and content as follows: (Title of Article, Author, Journal Title and Volume/lssue Copyright @ [year] copyright owner as specified in the Journal).

3. Please note that Wiley- $\mathrm{VCH}$ reserves the right to require changes to the Contribution, including changes to the length of the Contribution, as a condition of acceptance.

4. Please note that Wiley- $\mathrm{VCH}$ reserves the right, notwithstanding acceptance, not to publish the Contribution if for any reason such publication would in the reasonable judgement of Wiley-VCH, result in legal liability or violation of journal ethical practices.

\section{B. RETAINED RIGHTS}

Notwithstanding the above, the Contributor or, if applicable, the Contributor's Employer, retains all proprietary rights other than copyright, such as patent rights, in any process, procedure or article of manufacture described in the Contribution.

\section{PERMITTED USES BY CONTRIBUTOR}

1. Submitted Version. Wiley-VCH licenses back the following rights to the Contributor in the version of the Contribution as originally submitted for publication:

a. After publication of the final article, the right to self-archive on the Contributor's personal intranet page or in the Contributor's institution's/ employer's institutional intranet repository or archive. The Contributor may not update the submission version or replace it with the published Contribution. The version posted must contain a legend as follows: This is the pre-peer reviewed version of the following article: FULL CITE, which has been published in final form at [Link to final article].

b. The right to transmit, print and share copies with colleagues.

2. Accepted Version. Reuse of the accepted and peer-reviewed (but not final) version of the Contribution shall be by separate agreement with Wiley-VCH. Wiley-VCH has agreements with certain funding agencies governing reuse of this version. The details of those relationships, and other offerings allowing open web use are set forth at the following website:

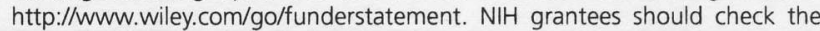
box at the bottom of this document.

3. Final Published Version. Wiley-VCH hereby licenses back to the Contributor the following rights with respect to the final published version of the Contribution:

a. Copies for colleagues. The personal right of the Contributor only to send or transmit individual copies of the final published version to colleagues upon their specific request provided no fee is charged, and further-provided that there is no systematic distribution of the Contribution, e.g. posting on a listserve, website or automated delivery. For those Contributors who wish to send high-quality e-prints, purchase reprints, or who wish to distribute copies more broadly than allowed hereunder (e.g. to groups of colleagues or mailing lists), please contact the publishing office.

b. Re-use in other publications. The right to re-use the final Contribution or parts thereof for any publication authored or edited by the Contributor (excluding journal articles) where such re-used material constitutes less than half of the total material in such publication. In such case, any modifications should be accurately noted.

c. Teaching duties. The right to include the Contribution in teaching or training duties at the Contributor's institution/place of employment including in course packs, e-reserves, presentation at professional conferences, in-house training, or distance learning. The Contribution may not be used in seminars outside of normal teaching obligations (e.g. commercial seminars). Electronic posting of the final published version in connection with teaching/training at the Contributor's institution/place of employment is permitted subject to the implementation of reasonable access control mechanisms, such as user name and password. Posting the final published version on the open Internet is not permitted.

d. Oral presentations. The right to make oral presentations based on the Contribution

4. Article Abstracts, Figures, Tables, Data Sets, Artwork and Selected Text (up to 250 words).

a. Contributors may re-use unmodified abstracts for any non-commercial purpose. For on-line uses of the abstracts, Wiley-VCH encourages but does not require linking back to the final published versions.

b. Contributors may re-use figures, tables, data sets, artwork, and selected text up to 250 words from their Contributions, provided the following conditions are met:

(i) Full and accurate credit must be given to the Contribution.

(ii) Modifications to the figures, tables and data must be noted. Otherwise, no changes may be made.

(iii) The reuse may not be made for direct commercial purposes, or for financial consideration to the Contributor.

(iv) Nothing herein shall permit dual publication in violation of journa ethical practices. 


\section{CONTRIBUTIONS OWNED BY EMPLOYER}

1. If the Contribution was written by the Contributor in the course of the Contributor's employment (as a "work-made-for-hire" in the course of employment), the Contribution is owned by the company/employer which must sign this Agreement (in addition to the Contributor's signature) in the space provided below. In such case, the company/employer hereby grants to Wiley-VCH the full and exclusive rights comprised in the Contribution as specified in paragraph $\mathrm{A}$ above throughout the world for the duration of the statutory term of protection.

2. In addition to the rights specified as retained in paragraph $B$ above and the rights granted back to the Contributor pursuant to paragraph C above, WileyVCH hereby grants back, without charge, to such company/employer, its subsidiaries and divisions, the right to make copies of and distribute the final published Contribution internally in print format or electronically on the Company's internal network. Copies so used may not be resold or distributed externally. However the company/employer may include information and text from the Contribution as part of an information package included with software or other products offered for sale or license or included in patent applications. Posting of the final published Contribution by the institution on a public access website may only be done with Wiley-VCH's written permission, and payment of any applicable fee(s). Also, upon payment of Wiley-VCH's reprint fee, the institution may distribute print copies of the published Contribution externally.

\section{E. GOVERNMENT CONTRACTS}

In the case of a Contribution prepared under U.S. Government contract or grant, the U.S. Government may reproduce, without charge, all or portions of the Contribution and may authorize others to do so, for official U.S. Govern- ment purposes only, if the U.S. Government contract or grant so requires. (U.S. Government, U.K. Government, and other government employees: see notes at end.)

\section{F. COPYRIGHT NOTICE}

The Contributor and the company/employer agree that any and all copies of the final published version of the Contribution or any part thereof distributed or posted by them in print or electronic format as permitted herein will include the notice of copyright as stipulated in the Journal and a full citation to the Journal as published by Wiley-VCH.

\section{G. CONTRIBUTOR'S REPRESENTATIONS}

The Contributor represents that the Contribution is the Contributor's original work, all individuals identified as Contributors actually contributed to the Contribution, and all individuals who contributed are included. If the Contribution was prepared jointly, the Contributor agrees to inform the co-Contributors of the terms of this Agreement and to obtain their signature to this Agreement or their written permission to sign on their behalf. The Contribution is submitted only to this Journal and has not been published before. (If excerpts from copyrighted works owned by third parties are included, the Contributor will obtain written permission from the copyright owners for all uses as set forth in WileyVCH's permissions form or in the Journal's Instructions for Contributors, and show credit to the sources in the Contribution.) The Contributor also warrants that the Contribution contains no libelous or unlawful statements, does not infringe upon the rights (including without limitation the copyright, patent or trademark rights) or the privacy of others, or contain material or instructions that might cause harm or injury.

\section{CHECK ONE BOX:}

XContributor-owned work
attach additional signature
pages as necessary

Type or print name and title

Company/Institution-owned work

(made-for-hire in the

course of employment)

Company or Institution (Employer-for-Hire)

Date

Authorized signature of Employer

Date

U.S. Government work

Note to U.S. Government Employees

A contribution prepared by a U.S. federal government employee as part of the employee's official duties,

or which is an official U.S. Government publication, is called a "U.S. Government work," and is in the public domain in the United States. In such case, the employee may cross out Paragraph A.1 but must sign (in the Contributor's signature line) and return this Agreement. If the Contribution was not prepared as part of the employee's duties or is not an official U.S. Government publication, it is not a U.S. Government work.

U.K. Government work (Crown Copyright)

\section{Note to U.K. Government Employees}

The rights in a Contribution prepared by an employee of a U.K. government department, agency or other Crown body as part of his/her official duties, or which is an official government publication, belong to the Crown. U.K. government authors should submit a signed declaration form together with this Agreement. The form can be obtained via http://www. opsi.gov.uk/advice/crown-copyright/copyright-guidance/ publication-of-articles-written-by-ministers-and-civil-servants.htm

Other Government work

\section{Note to Non-U.S., Non-U.K. Government Employees}

If your status as a government employee legally prevents you from signing this Agreement, please contact the editorial office.

NIH Grantees 